\title{
Religião e nação na Europa no século XIX:
}

\section{algumas notas comparativas ${ }^{1}$}

\author{
HEINZ-GERHARD HAUPT
}

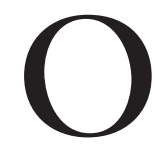

DESMORONAMENTO da religião durante o processo de secularização foi uma das condições do sucesso do nacionalismo desde o fim do século XVIII na Europa. Essa, pelo menos, é a opinião de Hans-Ulrich Wehler (2003), historiador alemão, em seu livro recente sobre o nacionalismo. Em sua óptica, a crítica da religião durante o século das Luzes, a separação entre a Igreja e o Estado como se manifesta na constituição civil do clero durante a Revolução Francesa e a perda de uma orientação religiosa por amplas camadas da população teriam criado um "vazio" em que o nacionalismo poderia ter sido inserido e em que teria tomado o lugar da religião como sistema de fé e orientação (ibidem).

Essa substituição teria sido possível porque religião e nacionalismo vão compartilhar alguns traços e funções comuns: fornecerão mitos de origem, santos e mártires, objetos, lugares e cerimônias santas, um sentido do sacrifício e das funções de legitimação e mobilização. O período jacobino na França e as guerras antinapoleônicas seriam, nessa perspectiva, as primeiras manifestações do que a historiadora francesa Mona Ozouf (1976) chamou de "transferência de sacralidade" do domínio religioso estrito para a nação. É assim que os sanscullottes falavam de sua "sainte pique", celebravam a Revolução diante dos "altares da pátria” e partiam para lutar em guerras santas. ${ }^{2}$

Em uma perspectiva histórica, essa abordagem suscita, porém, algumas críticas. A idéia de um vazio, um vacuum, sublinha metaforicamente a profundidade de uma mudança ocorrida, mas não revela a complexidade das constelações e das evoluções históricas que se caracterizam por sobreposições de tendências, relações entre essas, fusão ou repulsão parcial. A "semelhança do não-contemporâneo" - essa fórmula do filósofo Ernst Bloch (1935) que põe o acento na coexistência de diferentes sistemas de fé e explicação do mundo no interior de uma dada sociedade, que possuem, além do mais, uma longevidade e temporalidade diferentes - parece mais adequada para caracterizar e interpretar situações históricas complexas e momentos de mudança histórica. A discussão recente sobre o nacionalismo também tomará distância dessa afirmação. Essa discussão tende

a substituir uma imagem rígida do nacionalismo, fundada em uma idéia primordial da nação que aí encontra sua expressão política, com uma concepção dinâ- 
mica de um sistema de discurso que se nutre de fontes diferentes: imagens da sociedade, dos sexos, das condições étnicas, do passado etc., das quais a religião constitui somente uma parte. ${ }^{3}$

A mudança ocorrida nos estudos sobre o nacionalismo durante os anos 1980 levaria, ao contrário, a refletir sobre o lugar do religioso diante de outras referências culturais na ideologia nacionalista. Enfim, os estudos sobre a história das religiões durante as duas últimas décadas deram uma imagem mais atenuada de suas evoluções. No lugar de acentuar a crítica da religião como se manifesta durante o século das Luzes e no século XIX, os estudos insistem sobre as formas diferentes de subsistência, ou seja, de renascimento do "religioso" nas sociedades européias.

1. É verdade que essa religiosidade não se exprime necessariamente no quadro das confissões estabelecidas - ainda que essas permaneçam importantes -, mas em formas diferentes. Mesmo os republicanos franceses não escapavam de sua atração, ainda quando, como anticlericais, se reuniam durante o Segundo Império em sessões ocultistas para fazer mover as mesas! (Nord, 1995, p.216ss). No final do século XIX e no começo do XX, o teólogo Friedrich Wilhelm Graf (2004) constatou a existência de diferentes mercados religiosos em que as confissões estabelecidas entravam em competição com outros sistemas de fé e explicação do mundo (cf. Lehmann \& Krumeich, 2000).

Nessa perspectiva, não há muito sentido constatar um "vazio" criado pela secularização, mas é preciso, antes, perguntar a qual tipo de religiosidade o nacionalismo do século XIX pôde se unir. A historiografia do nacionalismo não respondeu completamente a esse interrogativo, embora tenha acentuado a ligação existente entre nacionalismo e sistemas religiosos.

2. Elias Canetti (1992), originário do "melting pot" nacional e étnico dos Bálcãs e observador crítico dos movimentos de massa do século XX, insiste em que as nações podem ser consideradas como religiões e que é principalmente durante as guerras que os sentimentos nacionais e religiosos se misturam. Norbert Elias (1989), historiador da civilização européia, acentua que a nação e o nacionalismo são sistemas de crença importantes, e acaba por considerar o nacionalismo a fé mais importante do século XX. Foi Georg Mosse (1976) quem sublinhou o fato, em seu livro sobre a nacionalização das massas, de que o nacionalismo não é somente um movimento político e social, mas utiliza também uma linguagem e símbolos religiosos. Em sua óptica, o nacional-socialismo é a realização dessa osmose entre a nação e a religião no interior da cultura política alemã (cf. Echternkamp \& Müller, 2002). Mas já na origem da pesquisa científica sobre o nacionalismo, Carlton J. Hayes (1926) constatou que o nacionalismo é uma religião, pois possui rituais e mártires e desenvolve uma mitologia nacional particular. O historiador americano Eugen Weber (1986), enfim, observou que o historiador pode ser considerado o sacerdote da nação, porque ajuda a fornecer ao nacionalismo uma legitimação histórica. 
$\mathrm{Na}$ realidade, o debate historiográfico não diz respeito a saber se a primazia deve ser dada à religião ou à nação. Os trabalhos mais inovadores procuram principalmente colocar em evidência os processos de nacionalização da religião e de "sacralização" da nação (Walkenhorst, 1996, p.503-29). Desse modo, eles insistem sobre o valor de abordagens diferentes. Em um estudo dos discursos, eles podem se interrogar, retomando uma categorização de O'Brien (1988), se a nação é considerada, em seus posicionamentos, como eleita, sagrada ou divina. No último caso, a nação será situada entre as divindades e fora de toda possível contestação terrestre. É também importante observar em detalhe se a nação é associada à idéia de sacrifício e como esse sacrifício é legitimado.

Já os trabalhos que se concentram sobre o simbolismo da nação vão em outra direção e se interrogam em que medida esse simbolismo foi tomado das religiões e das confissões existentes, ou foi desenvolvido em competição com essas. ${ }^{4}$ Os atores desse processo também representam um papel primordial. Os sacerdotes e sua influência, os intelectuais e seu público, os homens políticos e suas estratégias são as relações mais importantes que intervêm durante os contatos entre religião e nação.

Muitas análises, por mais diferentes que sejam, acentuam a amplidão dos contatos entre nacionalismo e religião e insistem em sua fusão e osmose. Todavia, cancela-se facilmente um fator de diferença nessas afirmações, ou seja, o fato de que a religião, na definição de si mesma, assim como em sua mensagem, tende em direção do além, e é, por isso, menos submetida à prova do real. Ou, para dizê-lo em outro modo: o valor da mensagem moral e ética da religião não depende, senão de forma extremamente parcial, do sucesso terrestre dessa religião. Essa é uma diferença fundamental com relação ao nacionalismo nos séculos XIX e XX. Suas promessas de sucesso, de sobrevivência ou de bem-estar devem ser mantidas, e, se não o são, a legitimação religiosa não ajuda a assegurar a sobrevivência dos representantes da nação.

O imperador Guilherme II podia invocar o direito divino como fonte de sua dinastia e de seu governo, diante das derrotas alemãs: no entanto, durante a Primeira Guerra Mundial, a sua legitimidade se despedaça inexoravelmente. Essa diferença também convida o historiador a não privilegiar as representações discursivas do nacionalismo, mas a olhar, em detalhe, para a amplidão de suas realizações concretas e a ligação entre as promessas feitas e os resultados obtidos (cf. Haupt \& Langewiesche, 2001, 2004).

As notas seguintes se concentram em uma fase particular da relação entre nação e religião, ou seja, na segunda metade do século XIX e na primeira década do século XX. Essa fase foi caracterizada em alguns países europeus por processos de Nation building. Essa expressão valoriza uma função importante do nacionalismo, o seu efeito de integração e modernização das sociedades. Ela pode ser utilmente distinta da formação de Estados-nação tal como foi descrita, por exemplo, por Theodor Schieder e da elaboração de uma ideologia naciona- 
lista como valor supremo de um sistema de fé, ainda que a Nation building não possa ser considerada sem suas ligações com os outros componentes do nacionalismo. Karl W. Deutsch (1953) foi quem valorizou a importância dos sistemas de comunicação e interdependência das diferentes partes de uma sociedade que se estabelecem durante o processo de Nation building. Eugen Weber (1976) ofereceu, no que diz respeito à França, uma análise empírica desse processo, estudando, entre outros, o estabelecimento do mercado, das escolas, do serviço militar. Siegfried Weichlein (2006), por sua vez, dedicou-se à análise da unificação do Império alemão observando as vias de comunicação entre suas diversas partes.

Os Estados nacionais, todavia, não agiam somente como fatores de comunicação, mas tentavam também se impor como princípios organizadores das sociedades, como fonte de legitimidade e como referente de moralidade cívica. Nessa obra de penetração, os Estados Nacionais enfrentaram resistências, entre as quais as mais fortes e ativas foram as da Igreja Católica. Ela se opunha à intervenção do Estado nos sistemas de ensino, no funcionamento interno das Igrejas, assim como na organização pública das cerimônias unificadoras, dos heróis míticos, das ideologias integradoras.

As batalhas relativas ao lugar das Igrejas nas sociedades nacionais eram sempre acompanhadas por um conflito sobre a questão de quem vai deter o monopólio de interpretação do passado e do presente nessas sociedades. Philip Schlesinger (1987) acentuou a importância desses conflitos, afirmando que "as culturas nacionais não são simples depósitos de símbolos compartilhados em relação aos quais toda a população se coloca de forma idêntica. Antes, devem ser considerados como lugares de contestação em que ocorrem disputas sobre definições”. Friedrich Wilkhelm Graf (Graf, 2004, p.305) foi ainda mais categórico constatando: "os inventores da nação necessitam de símbolos lingüísticos para poder fabricar uma comunidade forte coesa emocionalmente" (cf. Durkheim, 1897-1898, p.20).

Essas lutas entre, pelo menos, dois sistemas de símbolos, duas lógicas de integração e duas organizações da memória coletiva e oficial opuseram, em vários Estados europeus, o Estado e a Igreja Católica, de Portugal a Itália, da França à parte checa do Império Austro-Húngaro. Nesses conflitos, as lutas de poder para o predomínio efetivo e/ou simbólico ocorriam nos diferentes Estados em formas semelhantes ou diferentes. As observações seguintes vão se concentrar sobre essas semelhanças e diferenças, apoiando-se no exemplo da França, da Itália, da parte checa do Império Austro-Húngaro e da Alemanha durante as décadas antes da Primeira Guerra Mundial. Por meio dessa escolha, de certo modo arbitrária, esperamos encontrar uma variedade de situações diferentes que expliquem os conflitos entre confissões, mas também os conflitos entre os Estados nacionais recentemente criados e a Igreja Católica, assim como o lugar de um movimento nacional diante da Igreja Católica. 
Na França, na Itália e na Checoslováquia, o Estado ou uma corrente laica entrou, durante o século XIX, em conflito com a Igreja Católica. ${ }^{5}$ Essa oposição era mais antiga na França. Com efeito, durante a Revolução Francesa, o Estado revolucionário obrigou o clero a um juramento cívico e provocou, portanto, um cisma, no interior da Igreja, entre os sacerdotes que juravam e os que se recusavam a jurar. A oposição entre duas lealdades - revolucionária, por um lado, católica e contra-revolucionária, por outro - estava na origem da guerra civil desencadeada na Vendéia (Martin, 1996). Se, sob Napoleão, essa oposição foi atenuada, em particular por uma concordata com a Santa Sé, ela novamente se desencadeou sob a Restauração, quando a Monarquia se apoiou na Igreja. Mas é durante a Terceira República que o conflito entre a Igreja e o Estado encontrou sua expressão mais radical.

Sustentar a República e declarar-se pelo progresso político e social eram equivalentes a anticlericalismo; defesa da Monarquia e oposição ao movimento republicano e, a fortiori, socialista eram o mesmo que a defesa da fé cristã e da Igreja Católica. Seguindo a palavra de ordem de Gambetta: “o clericalismo, eis o inimigo", os republicanos vitoriosos propuseram leis limitando o poder institucional da Igreja Católica (McManners, 1972, p.2327-58; Mollenhauer, 2004, p.202-30). Com a legislação escolar e instituindo a escola laica, gratuita e obrigatória, reduziram um campo de ação privilegiado da Igreja Católica. Em 1880, laicizaram os hospitais, mantidos antes pela Igreja; em 1884, o divórcio foi legalizado, e em 1889, uma lei decretava que os sacerdotes eram obrigados a fazer o serviço militar como todos os cidadãos. A atuação prática da lei de 1905 sobre a separação entre a Igreja e o Estado dava lugar a um conflito por vezes violento entre os fiéis e a polícia. ${ }^{6} \mathrm{O}$ conflito entre as "duas Franças" atingiu então seu ponto mais forte e marcou profundamente a vida pública e intelectual.

Na Itália, diferentemente da França, um acordo entre a Santa Sé e o movimento nacional parecia ser possível no período anterior à revolução de 1848 . Mas, como o papa se colocava do lado das forças contra-revolucionárias, a Igreja se isolou, com sua hostilidade à unidade nacional, e os sacerdotes que participavam da unificação nacional tiveram que enfrentar problemas com a hierarquia eclesiástica (Papenheim, 2003, p.202-36). Essa hostilidade se exprimiu dos dois lados após a unidade nacional. O Estado reagiu ao questionamento do governo e do Estado confiscando os bens da Igreja, obrigando aos seminaristas e sacerdotes o serviço militar e não reconhecendo o casamento religioso se não fosse acompanhado do casamento civil. O Estado praticou de forma draconiana seu direito de inspeção e consentimento à ordenação dos bispos, de modo que, em 1864, metade das dioceses não possuía bispos. A posição do papa endureceu quando, em 1864, condenou em seu "Syllabus" os "oitenta erros", e, em 1870, afirmou a infalibilidade do papa ao se pronunciar ex-cathedra.

O problema da sobrevivência do Estado pontifical era o obstáculo principal entre os dois atores. Os preconizadores do Risorgimento anunciavam a mar- 
cha sobre Roma e elevavam Roma a símbolo da unidade nacional reencontrada. Após a Roma dos césares e a dos papas, a Roma do povo deveria ser construída contra o papa. Com esses discursos, eles provocavam e aumentavam a desconfiança do papa, que temia que essa retórica expansionista conduzisse à abolição do Estado pontifício. Isso ocorreu em 20 de setembro de 1870 (Verocci, 1997, p.89ss). ${ }^{7}$ As décadas seguintes são caracterizadas por um comportamento fortemente anticlerical da esquerda, mas sob pressão também da direita, que procurou desenvolver uma política simbólica própria contra o papado, o qual se considerava "prisioneiro dentro do Vaticano".

Nas partes checas do Império Austro-Húngaro, somente na segunda metade do século XIX ocorreu um conflito entre a Igreja Católica e o movimento laico. A Igreja Católica estava dividida em uma Igreja boêmia e da Morávia, que se dedicavam ao culto dos santos regionais: São Venceslau, na Boêmia, São Cirilo e Metódio na Morávia (Hroch, 2005, p.55). Mas foi com a revolução de 1848 que o movimento nacional checo passou a se referir, cada vez mais, a Jan Hus, o herético queimado durante do Concílio de Constança. Hus era visto como um personagem importante, no interior de um movimento geral europeu em direção ao progresso e a uma religião individual fundada na ética. Nos escritos dos historiadores, nas peças de teatro e nos sermões, Hus era interpretado como um fator de sacralização da nação que, por seu sacrifício, teria permitido o renascimento da nação checa. Quanto mais a reação negativa, política e católica, contra essa interpretação atacava as doutrinas errôneas de Hus, mais sua figura ganhava popularidade e admiração. Em um período em que a Igreja Católica perdia importância, uma interpretação nacional e laica de Jan Hus tornava-se relevante e entrava em conflito com a Igreja Católica (Schulze-Wessel, 2004, p.135-50).

A situação alemã se distinguia fundamentalmente da dos outros países aqui mencionados, pois o Império alemão fora o teatro não de uma oposição entre o Estado laico e o catolicismo, mas de uma luta entre o protestantismo e o catolicismo, não tendo a comunidade judaica o mesmo peso numérico. Esse conflito tinha por objeto a hegemonia cultural na Alemanha e o monopólio da interpretação da história nacional. A identificação da nação alemã com a história do protestantismo, que se iniciara já antes de 1871, foi reforçada com a vitória da Prússia contra a Áustria em 1866, e com o resultado da guerra franco-alemã. $O$ protestantismo podia apelar à fé do imperador, que se definiu como protestante. Ele se colocava contra a fé católica, cuja lealdade para com o papa era interpretada como antinacional, e cuja conivência com os inimigos - freqüentemente católicos - da Prússia protestante era suspeitada. Durante o período do Kulturkampf - literalmente, da luta cultural - após 1871, a diferença entre o Império protestante e a Igreja Católica explodiu. ${ }^{8}$

Em dezembro, foi proibido ao clero criticar ex-cathedra o Império e sua constituição. Um ano depois, a Prússia decidiu excluir da inspeção da Escola todos os católicos. No mesmo ano, as casas dos jesuítas foram fechadas e seus 
membros estrangeiros foram expulsos da Alemanha. Desde então, os sacerdotes católicos deviam ser cidadãos alemães e deviam passar pelas escolas e faculdades de teologia estatais. O Estado se reservava o direito de nomear os bispos e ameaçava com multas aqueles que preferiam deixar vagos seus postos. Nesse conflito, os católicos foram percebidos como os inimigos do interior, e chegou-se a afirmar que houve uma reconfessionalização da vida pública e privada: ocorreram lutas entre estudantes de confissões diferentes, os casamentos interconfessionais tornaram-se mais difíceis, os consumidores escolhiam lojas administradas por comerciantes de sua confissão. ${ }^{9}$

O ataque estatal aos direitos e costumes da Igreja Católica levou a uma forte resistência dos católicos, que recusavam seguir as leis, organizavam movimentos de protesto e não se associavam aos feriados de comemoração nacional, como o Dia de Sedan, que comemorava a batalha decisiva da guerra franco-alemã. Na organização dos "meios políticos", como Rainer M. Lepsius os definiu, o meio católico acabava por organizar a maioria dos eleitores católicos, independentemente de sua origem social (Laube, 2001, p.293-332). No Império alemão, o catolicismo se encontrava em uma situação difícil, pois devia tentar se inserir em uma cultura nacional, em uma história nacional e em uma galeria de heróis nacionais definidos pelos protestantes. Considerando que o catolicismo defendera, por muito tempo, uma Alemanha sob o domínio da Áustria (católica), encontrou-se em dificuldade com a vitória da Prússia (protestante). Além do mais, sua composição socioprofissional o prejudicava, pois o protestantismo foi defendido pela grande maioria dos membros da burguesia esclarecida, cuja importância era menor no interior do catolicismo. Como os membros dessa burguesia possuíam uma posição destacada no movimento nacional alemão, os católicos tinham menos espaço para se impor.

Esses conflitos, cujo quadro geral pode apenas ser aqui esboçado, podem ser analisados de modos diferentes. Uma interpretação interessante seria interrogar sobre a envergadura da ação estatal e sobre os efeitos, nas sociedades, da legislação, cujo arsenal se assemelhava nos vários países. Seria possível, assim, escrever um capítulo de uma história do State building, e estabelecer em que medida o Estado nacional moderno pôde se confrontar com a força institucional e de mobilização do catolicismo. Aparentemente, a importância e a eficácia da ação estatal não devem ser exageradas. Os limites da intervenção estatal foram notados mesmo no Império alemão, no qual se reconhece uma organização estatal sólida: "o alcance modesto do Estado do século XIX, cujo balanço era de cerca $2 \%$ do que é atualmente, implica que as leis eram aplicadas de forma fragmentária e reduzida" (Burleigh, 2005, p.331).

Devemos, porém, aqui, ler esses conflitos no quadro da relação entre religião e nação. Pois os protagonistas não tentavam somente nacionalizar a religião - o Império alemão é um exemplo evidente -, mas também imprimir uma marca religiosa na nação. Friedrich Wilhelm Graf (2004) distinguiu nesse contexto dois 
casos: inicialmente, as construções religiosas da nação, que procuram superar o quadro das confissões existentes para encontrar, em um passado longínquo, às vezes mítico, o fundamento da nação. Essas não mais se interessam pela contribuição dos mitos de origem ou das histórias nacionais para a construção da nação, mas postulam um fundo mais rígido e imutável. Aí se colocariam as referências à raça, à terra e ao sangue derramado em uma interpretação "völkisch" da nação.

Uma segunda tendência seria a que constituiria a nação como uma comunidade de fiéis utilizando símbolos cristãos para sacralizar a nação, referindo-se à liturgia religiosa para comemorar a nação, e desenvolvendo uma história da salvação nacional (ibidem, p.302ss). No estudo dos exemplos históricos, não há muito sentido distinguir os países em que houve, principalmente, uma sacralização da nação, dos outros, onde se assiste a uma nacionalização do sagrado. Os dois processos são complementares, ainda quando divergem do ponto de vista sistemático. O primeiro se refere a uma reinterpretação das figuras nacionais e à instauração de uma religião civil como Jean-Jacques Rousseau (2005) tinha desenvolvido em suas "Considerações sobre o governo da Polônia"; o segundo se caracteriza por uma utilização nacional das figuras bíblicas, dos santos ou dos personagens da história das Igrejas.

No capítulo da nacionalização da religião, deve-se considerar, na Alemanha, o culto de Martinho Lutero (Schweiger, 1982). O reformador foi visto e comemorado como herói nacional tendo defendido a Alemanha contra o papa e o catolicismo. Nessa perspectiva, a Reforma foi celebrada como pré-história da unidade nacional alemã. Por ocasião do $400^{\circ}$ aniversário de seu nascimento, em 10 de novembro de 1883 , teriam sido pronunciados quarenta mil discursos na Alemanha sobre os méritos do reformador; foi criada uma Fundação Lutero para financiar os estudos universitários dos filhos de pastores e professores e foi construída e inaugurada uma enorme quantidade de monumentos em honra de Lutero. A referência a Lutero e a uma tradição nacional protestante servia também para distinguir, na história e na atualidade, segundo uma construção maniqueísta, os que favoreciam o surgimento da nação e os que se opunham a esse. A Idade Média era vista, nessa perspectiva, como sombria e ineficaz, e a Igreja Católica, como ultramontana e avassalada a Roma. Os países europeus que eram vistos como inimigos da nova nação alemã, como a França, em sua maioria católica, eram vistos como "podres” por causa do ultramontanismo que aí reinava. Com muitas iniciativas e recursos, o protestantismo conseguiu, sob o Império, promover uma confessionalização da nação e uma nacionalização da religião.

Os católicos alemães respondiam com a mesma força e com argumentos semelhantes. Já em 1848, Ignaz von Döllinger pretendia que a “única verdadeira Igreja nacional é... a Igreja Católica” (apud Kuhlemann, 2004, p.41). Em uma retrospectiva histórica, o protestantismo foi interpretado como um movimento de secessão, destruindo a unidade nacional, proclamando idéias teológicas errôneas e sendo 
dirigido por indivíduos profundamente mundanos, cujo centro espiritual seria o estômago! Contra Lutero, os católicos mobilizavam, principalmente após 1848, Bonifácio, o "apóstolo dos alemães”, para acentuar que a nação alemã estava associada, em seu nascimento, à introdução do cristianismo. Bonifácio, cujo nome provém do latim bonum $f a-$ cio, era celebrado como aquele que, durante o século VIII d. C., recebeu do papa Gregório II a missão de cristianizar as províncias alemãs. Nessa ação

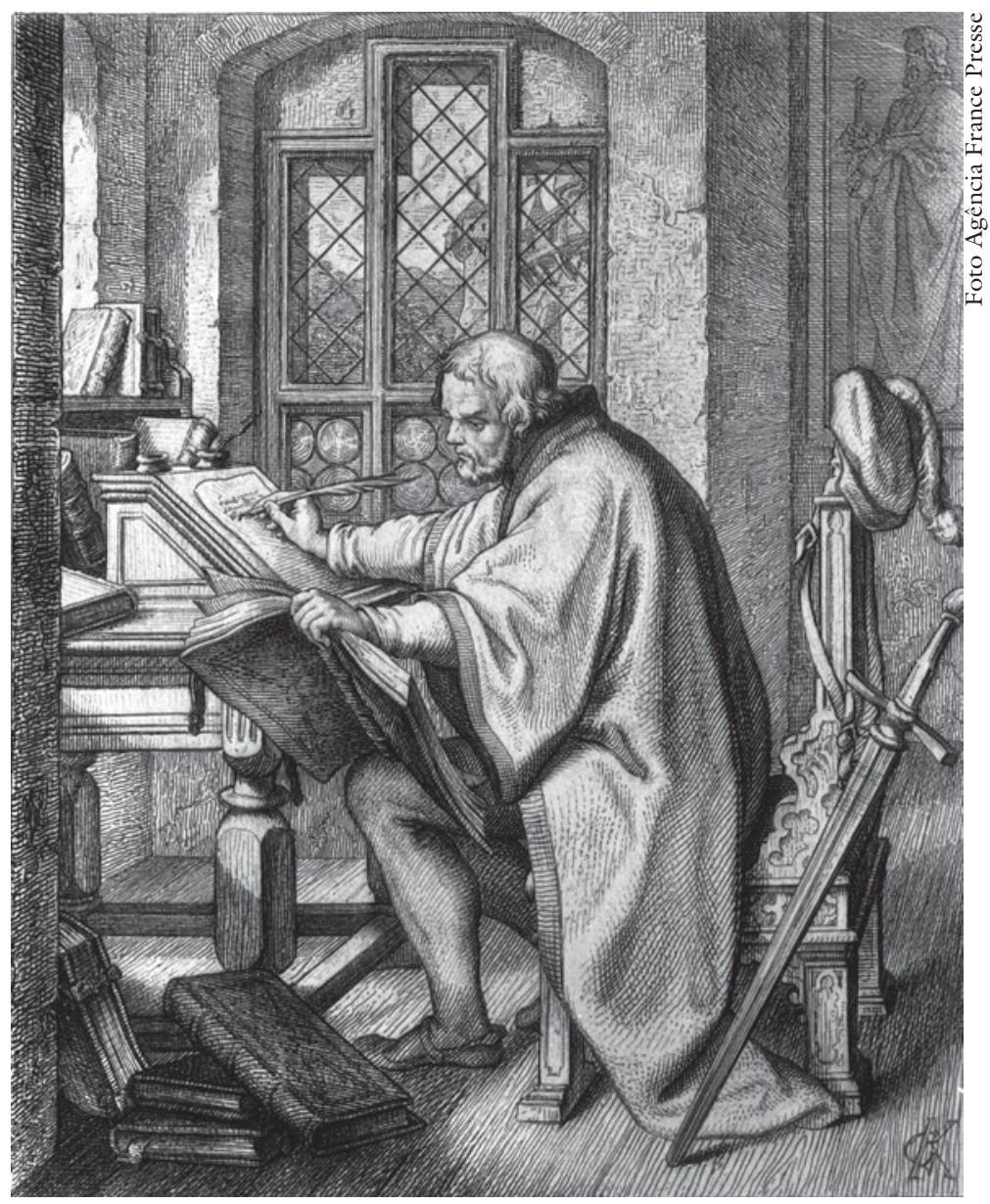

Martinho Lutero (1483-1546), teólogo e reformador protestante. missionária, foi assassinado - segundo a lenda - por pagãos da Alemanha do Norte. A ação missionária e civilizadora e o martírio eram, na perspectiva católica de Bonifácio, um bom exemplo da eficácia e da longevidade da luta católica para a unidade da Alemanha. Uma Associação Bonifácio foi criada em 1849 para apoiar os católicos que viviam em diáspora na Alemanha, e já em 1855 celebravase o $1.100^{\circ}$ aniversário da morte de Bonifácio. Em 1867, os bispos alemães se reuniram junto à tumba de Bonifácio. Kuhlemann constatou que esse culto do missionário contribuiu, certamente, para aumentar a consciência nacional dos católicos alemães.

No movimento nacional checo, Hus foi interpretado, após 1848, como o líder de um movimento de protesto nacional - os hussitas. Ele era venerado por suas ações, mas também como mártir nacional, que, por seu sacrifício, teria contribuído para liberar a nação checa. Como justamente nota Martin SchulzeWessel (2004), a referência a Jesus é evidente. Esse culto foi apoiado por 250 intelectuais de primeiro plano que, em 1868, partiram em peregrinação para Constança, onde Hus fora queimado como herético. Essa sacralização da nação encontrava muita ressonância nas camadas burguesas e intelectuais que, mesmo 
sendo católicas, aspiravam à criação de um Estado laico. Um conflito acentuado ocorreu entre o catolicismo, que acentuava sua distância das doutrinas heréticas de Hus, e um Hus laicizado e nacionalizado, quando a Associação Nacional Hus decidiu erigir um monumento a Hus em Praga, no Altstädter Ring, bem no lugar em que se encontrava uma estátua de Maria erguida após a Guerra dos Trinta Anos. Após debates virulentos e prolongados, obteve-se um compromisso: decidiu-se instalar a estátua de Hus ao lado da de Maria.

$\mathrm{Na}$ França, um tal esforço para nacionalizar uma figura da história eclesiástica ocorreu quando os republicanos tentaram nacionalizar o culto de Joana d'Arc, que tinha uma grande importância no interior da Igreja Católica. Como demonstrou Krumeich (1989), Joana d'Arc alcançara uma grande popularidade entre os fiéis católicos e na cultura popular (cf. Winock, 1997, p.4427-73). À "filha do povo", que, graças à inspiração divina, teria salvado o rei, os republicanos opunham uma Joana d'Arc traída pelo rei, pelos nobres e pela Igreja Católica, e que teve de morrer para salvar a França. Os republicanos enfileiravam entre os adversários de Joana D’Arc todos os que eles combatiam durante a Terceira República. Mas essa adaptação republicana de Joana D'Arc não obteve nenhuma repercussão popular. Ao contrário, os republicanos tiveram mais sucesso sacralizando os heróis nacionais quando os transferiam para o Panteão. $\mathrm{O}$ culto dos grandes homens da pátria utilizava muitos elementos da liturgia religiosa, mas, ao mesmo tempo, se opunha diretamente à Igreja Católica. Pois o Panteão substituíra a Igreja de Santa Genoveva. Essa decisão, tomada durante a Revolução de 1789, foi anulada durante o Segundo Império, mas foi renovada sob a Terceira República. A sepultura dos heróis nacionais em uma antiga igreja provocou forte reação dos católicos, que viam nisso uma profanação e um sacrilégio. Contudo, em 1855, Victor Hugo - o poeta nacional - foi transferido para o Panteão (Ben Amos, 2002).

Também o Estado laico italiano procurava, sob a pressão de uma esquerda laica, um simbolismo próprio e hostil à Igreja Católica. Na necessidade de criar os italianos após ter criado a Itália como Estado Nacional, os diferentes governos de direita procuravam encontrar, por meio de uma política da memória e da comemoração, uma posição de legitimidade mais forte junto à população italiana. Esse esforço os colocava em conflito com a Igreja Católica, que recusava colaborar com o Estado nacional italiano, ao qual acusava de ter despojado a Igreja do Estado Pontifical e dos bens eclesiásticos (Tobia, 1991). Os governos sucessivos, com efeito, entraram em guerra contra uma presença demasiado visível da iconografia católica, destruindo, em Roma, efígies e estatuetas de santos - como fizera a Terceira República francesa, que tinha oposto a Mariana republicana a Maria. Ao mesmo tempo, procuravam desenvolver um culto cívico para substituir ou, pelo menos, fazer concorrência à influência católica. O culto da Constituição, como existia já no Piemonte, não se mostrava particularmente mobilizador. Ao contrário, a celebração de Garibaldi e de Vitório Emanuel II como heróis da libertação nacional tinha maior repercussão popular. Como em outros países europeus, estátuas em seu favor, assim como celebrações, manifestavam a preocupação com 
uma referência cultural laica (Brice, 1998). A construção de um movimento em favor de Giordano Bruno, o pensador anticlerical, no Campo dei Fiori, em Roma, foi interpretada pela Igreja Católica como uma provocação, assim como a comemoração, em 1895, de 2 de setembro como a festa da tomada de Roma. Essa comemoração foi interpretada de forma diferente segundo as várias correntes políticas. A direita via nela a conclusão do processo de Nation building anticlerical, e o início de uma conciliação com a Igreja católica; a esquerda inseria essa comemoração em um processo de construção de uma Itália nova e secular.

Em uma perspectiva comparada, é surpreendente ver como as políticas da memória e simbólicas se as-

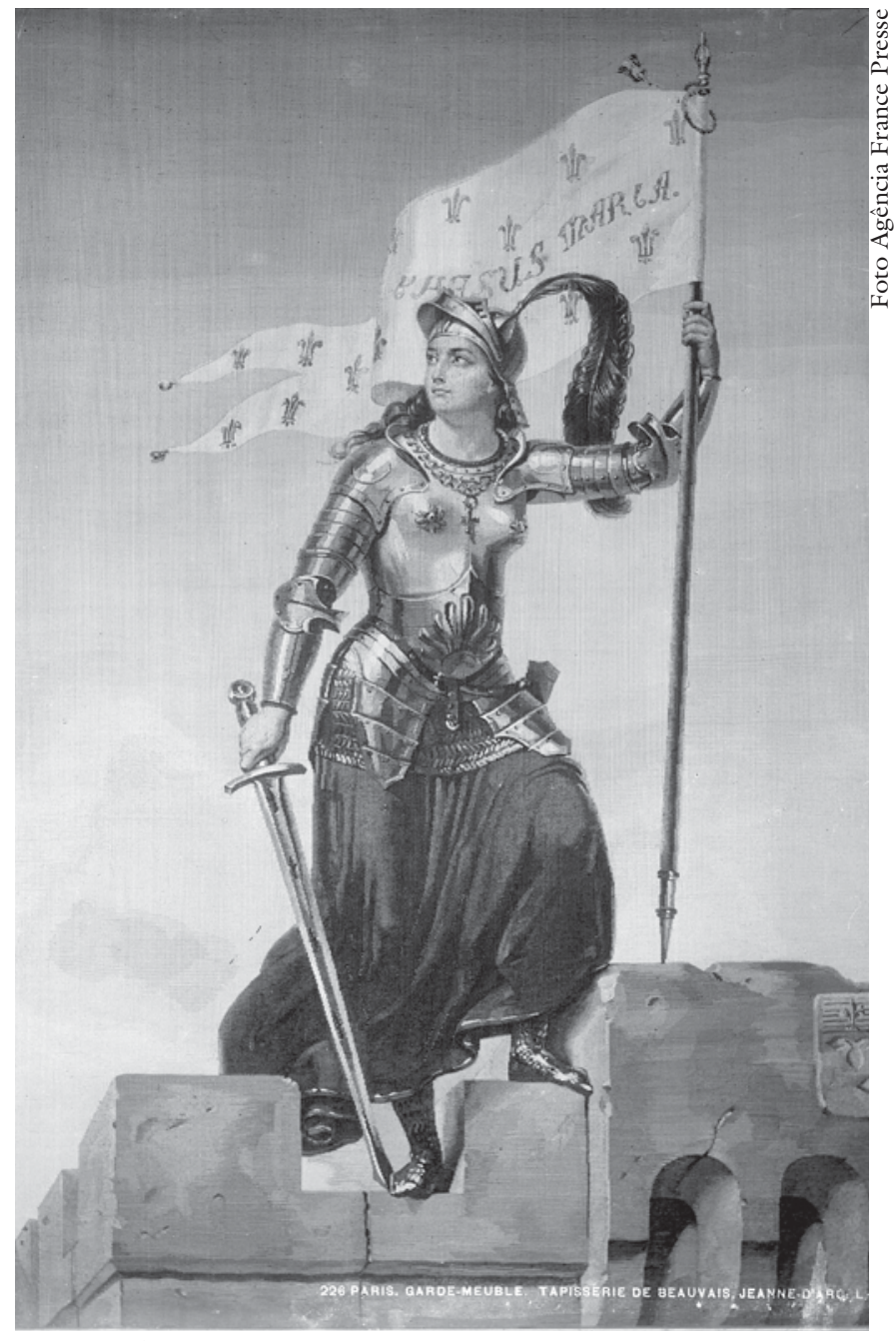

A heroina francesa Joana d'Arc (1412-1431). semelharam nas quatro sociedades que aqui mencionamos. Elas se apoiavam em figuras do passado, tanto para celebrar a longevidade da unidade nacional criada pela cristianização do país - como São Venceslau, na Checoslováquia; Bonifácio, na Alemanha; Joana d'Arc ou São Luís, na França - quanto para comemorar uma ruptura da unidade católica no passado como o início de uma evolução que conduzia ao Estado nacional do presente: Jan Hus, Martinho Lutero, Giordano Bruno, uma Joana d'Arc republicana podiam servir de exemplo. Nessa oposição, os personagens da história eclesiástica foram nacionalizados e introduzidos em uma construção histórica, em uma "invenção da tradição" (Hobsbawm\&Ranger, 1992). A nação e o Estado-nação que a essa se referia deviam ganhar legitimidade histórica e ser colocadas, para além das ações quotidianas, em uma esfera religiosa. A própria nação foi sacralizada com esses discursos e perdeu o caráter de uma construção contingente e histórica. Ela não foi definida de forma pluralista, aberta, mas como uma entidade fechada, única e holística. A sacralização da nação contribuía para dar-lhe esse aspecto obrigatório, exclusivo. 
Esse confronto entre duas versões diferentes da história nacional conduziu a conflitos entre historiadores e propagandistas, mas também a simbolizações diferentes. A ereção de estátuas, a escolha de nomes de ruas e dos feriados nacionais deu origem a duras oposições entre a Igreja Católica e o Estado Nacional laico. Essa oposição era particularmente forte na França e na Itália, mas também na parte checa do Império Austro-Húngaro. Aparentemente, o anticlericalismo foi mais forte na França, onde se unia a uma ampla gama de posições liberais, republicanas e socialistas. Foi mais controvertido na Itália, e tornou-se um cavalo-de-batalha no movimento nacional checo contra o governo de então. $\mathrm{Na}$ Alemanha, ao contrário, o anticlericalismo não tinha o mesmo peso que nos outros três países, ainda quando desenvolvido junto ao movimento social-democrata. A luta entre as duas confissões para a hegemonia cultural e o poder de imposição simbólica no Império foi predominante e influenciava as lutas simbólicas e as formas de manifestação escolhidas. Se, nos outros países europeus, o Estado laico devia lutar contra uma presença maciça da Igreja Católica, contra a qual devia afirmar sua legitimidade, suas narrativas e simbolismos nacionais - como na Itália ou na Checoslováquia -, ou mantê-la - como na França -, na Alemanha a situação era diferente. A Igreja Católica devia se inserir em uma tradição nacional que era definida pela maioria da população e pelo Império alemão como protestante e devia modificar os discursos que construíam a nação alemã excluindo os católicos como leais a um poder estrangeiro e hostil a uma versão protestante do passado alemão.

Seria tentador medir o impacto dessas lutas simbólicas na opinião pública e na população. Todavia, os estudos de recepção estão entre os mais difíceis exercícios de estilo histórico, pois as fontes são raras e os problemas metodológicos são grandes. Uma abordagem promissora para esse problema foi escolhida por Oliver Janz (2002, p.61-75), que estudou as referências religiosas utilizadas, durante a Primeira Guerra, pelos autores de publicações freqüentemente públicas, ou semipúblicas, para se lembrar dos oficiais e soldados italianos mortos nos campos de batalha. Pôde constituir um grupo de 2.300 escritos, dos quais $95 \%$ se referiam à nação, sem, no entanto, exprimir sentimentos anticlericais. Em sua análise, esses escritos não mostram o sucesso de uma campanha anticlerical, mas a simbiose entre uma interpretação nacional da guerra e a morte descrita em uma linguagem religiosa. Os mortos são vistos como mártires de uma guerra chamada "santa" e os textos exprimem um culto do sacrifício patriótico que permitiria - com uma clara referência religiosa - o renascimento de uma nova Itália. A semântica nacional e religiosa é estreitamente relacionada nesses textos. Esses podem, portanto, demonstrar que uma versão anticlerical da nação parece ter tido poucos efeitos; já a ligação entre as referências religiosas, a invocação da nação e a sorte individual está presente nos textos de comemoração.

Para medir a importância desse processo de nacionalização da religião e da sacralização da nação, pode-se também interrogar as conseqüências desses discursos nos anos anteriores à Primeira Guerra Mundial. Na Itália, a direita 
procurara chegar a um compromisso com a Igreja Católica e evitar manifestações e publicações que podiam ser consideradas anticlericais. Com efeito, a atitude da Igreja Católica também se modificava. Com a encíclica Rerum Novarum, o papa indicava certa abertura para o mundo moderno e permitia às Igrejas nacionais que se dirigissem a uma política de compromisso com os Estados Nacionais laicos (Burleigh, 2005 , p.365ss). Isso não produziu efeitos profundos na França, onde os católicos tinham acabado por adotar os símbolos

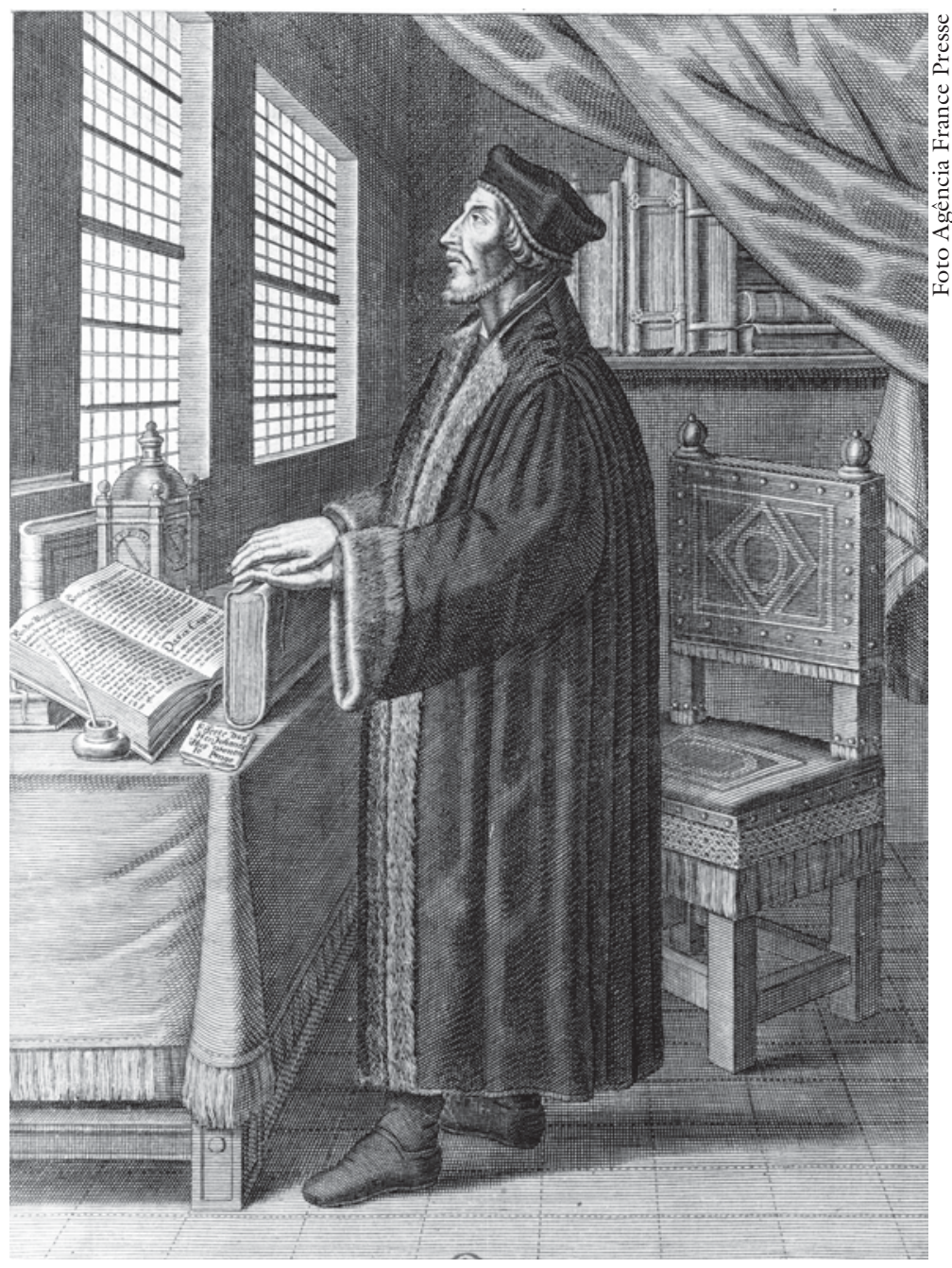

Jan Hus (1369-1415), pensador e reformador religioso.

nacionais, como a bandeira tricolor e a comemoração do 14 de julho, mas onde a separação da Igreja e do Estado de 1905 desencadeava novos conflitos e aumentava a ruptura entre os republicanos laicos e os fiéis católicos. Somente a Primeira Guerra Mundial permitiu à Igreja Católica participar da defesa da unidade nacional e da causa "sagrada" da nação, sem por isso saldar as diferenças fundamentais entre as “duas Franças" (Mollenhauer, 2004, p.228ss).

No que diz respeito à Alemanha, foi principalmente Kuhlemann (2004, p.46ss) quem se interessou pelos efeitos de uma confessionalização da nação. Ele acentua a importância dos pastores protestantes que, por causa do universalismo da fé, opõem-se a uma definição exclusiva da nação. Esses se encontram de acordo com os católicos liberais e burgueses, para pedir uma separação da Igreja e do Estado, e colaboram em âmbito municipal assim como em associações de caridade ou nos sindicatos cristãos. Por sua vez, os conservadores católicos e protestantes podem também se reencontrar na defesa da dinastia e da ordem estabelecida, diante da social-democracia em ascensão. Eles encontram-se de 
acordo na defesa da família, da religião e do Estado, temendo um Estado sem Deus. Eram, de certa forma, os precursores da Democracia Cristã, tal como aparecerá na Alemanha após 1945. Com certeza, a própria guerra conciliou as rupturas na Alemanha e contribuiu para unir os católicos alemães com a nação alemã mais do que ocorreu com seus correligionários franceses.

A aproximação mais importante e politicamente mais perigosa entre católicos e protestantes na Alemanha, e entre laicos e católicos na Checoslováquia, ocorreu sobre outra base. Quando o conflito em Praga sobre a colocação das estátuas de Maria e Hus foi resolvido com um compromisso, os discursos então pronunciados não se referiam às inimizades do dia anterior, mas procuravam construir uma unidade entre laicos e protestantes insistindo sobre temas nacionalistas e anti-semitas. É com a exclusão das minorias nacionais e religiosas que se concluiu a paz entre as duas forças opostas (Schulze-Wessel, 2004, p.143). Também na Alemanha, um estudo sistemático revelou que é principalmente após 1918 que a diferença entre uma definição católica e protestante da nação tende a desaparecer para dar lugar a uma definição que remonta até as origens da nação alemã e sublinha a ligação de sangue e raça entre os seus membros (Steinmetz, 2001, p.217ss). A evolução semântica chega, pois, atrasada em relação à evolução do nacionalismo alemão, que, já durante os anos 1890, tomara a direção de um nacionalismo exclusivo e fundado na origem étnica (ibidem). Quando a referência principal não foi a confissão, mas a origem étnica, os católicos puderam tornar-se facilmente membros da nação alemã e desfrutar de seus direitos. Mas essa definição "völkish" da nação alemã excluía não somente os poloneses, que viviam como a mais numerosa minoria católica na Alemanha, mas também os judeus. Um nacionalismo fundado na origem étnica e formulado de maneira exclusiva era igualmente hostil à criação de uma república como a de Weimar, e a essa se opunha. Ele oferecia as armas e sugeria os inimigos para o nacional-socialismo.

Notas

1 Este artigo baseia-se nos resultados de duas conferências que Dieter Langewiesche (Tübingen) e eu organizamos e publicamos: Nation und Religion in der deutschen Geschichte (Frankfurt; New York, 2001); Nation und Religion in Europa. Mebrkonfessionelle Gesellschaften im 19. und 10 Jahrhundert (Frankfurt; New York, 2004). Os resultados foram apresentados e discutidos em um seminário na Escola de Doutorado de San Marino. Agradeço aos pesquisadores seus comentários e críticas.

2 Cf., recentemente, Martin (1996).

3 Cf., por exemplo, a aplicação de uma análise construtivista em um estudo empírico (Müller, 2002). Para um quadro da evolução da pesquisa, ver Eley \& Suny (1996, p.3-37).

4 Ver, por exemplo, o número especial de Temps Modernes, v.550, Mai 1992: "Symbolique et identité nationale dans l'Europe contemporaine". 
5 Para a evolução geral, ver Rémond (1998) e Burleigh (2005).

6 Ver o pequeno livro de Mayeur (1966).

7 Para essa argumentação, ver Janz (2004, p.231-52).

8 Para a história do Kulturkampf em um contexto internacional, ver Burleigh (2005, p.31lss).

9 É fundamental o artigo de Kuhlemann (2004, p.27-63).

Referências bibliográficas

BEN AMOS, A. Funerals, Politics, and Memory in Modern France, 1789-1996. Oxford, New York: Oxford University Press, 2002.

BLOCH, E. Erbschaft unserer Zeit (1935), Suhrkamp (Werke Bd. 4).

BRICE, C. Le Vittoriano. Monumentalité publique et politique à Rome. Rome: Ecole francaise de Rome, 1998.

BURLEIGH, M. Earthly Powers. The Clash of Religion and Politics in Europe from the French revolution to the Great War. New York: Cambridge University Press, 2005.

CANETTI, E. Masse und Macht. Claasen Düsseldorf, 1992.

DEUTSCH, K. W. Nationalism and social communication. An inquiry into the Foundations of Nationalism. Cambridge Mass.: MIT Press, 1953.

DURKHEIM, E. De la définition des phénomènes religieux. L'Année Sociologique, v.2, p.20, 1897-1898.

ECHTERNKAMP, J.; MÜLLER, S. O. (Ed.) Die Politik der Nation. München: Oldenbourg, 2002.

ELEY. G.; SUNY, R. G. Introduction: From the Moment of Social History to the Work of Cultural Representation, Becoming national Oxford University Press. New York, 1996.

ELIAS, N. Studien über die Deutschen. Machtkämpfe und Habitusentwicklung im 19. und 20. Jahrhundert. Frankfurt: Suhrkamp, 1989.

GRAF, F. W. Die Wiederkehr der Götter. Religion in der modernen Kultur. Beck, München, 2004.

HAUPT, H.-G.; LANGEWIESCHE, D. Nation und Religion in der deutschen Geschichte. Campus Frankfurt; New York, 2001.

- Nation und Religion in Europa. Mebrkonfessionelle Gesellschaften im 19. und 10 Jahrbundert. Campus Frankfurt; New York, 2004.

HAYES, C. J. H. Essays on Nationalism. New York: Cambidge University Press, 1926.

HOBSBAWM, E. J.; RANGER, T. O. The Invention of Tradition. New York: Cambridge University Press, 1992.

HROCH, M. Das Europa der Nationen. Die moderne Nationsbildung im europäischen Vergleich. Göttingen: Vanmdenhoeck \& Ruprecht, 2005.

JANZ, O. Konflikt, Koexistenz und Symbiose. Nationale und religiöse Symbolik in Italien vom Risorgimento bis zum Faschismus. In: HAUPT, H.-G.; LANGEWIESCHE, D. Nation und Religion in Europa. Mehrkonfessionelle Gesellschaften im 19. und $20 \mathrm{Jahr}$ bundert. Campus Frankfurt; New York, 2004. p.231-52. 
JANZ, O. Zwischen Trauer und Triumph. Politischer Totenkult in Italien nach dem Ersten Weltkrieg. In: DÜLFFER, J.; KRUMEICH, G. (Ed.) Der verlorene Frieden. Politik und Kriegskultur nach 1918. Klartext, Essen, 2002. p.61-75.

KRUMEICH, G. Jeanne d'Arc in der Geschichte: Historiographie - Politik - Kultur. Thorbecke. Sigmaringen, 1989.

KUHLEMANN, F. M. Konfessionalisierung der Nation? Deutschland im 19 und frühen 20. Jahrhundert. In: HAUPT, H.-G.; LANGEWIESCHE, D. Nation und Religion in Europa. Mehrkonfessionelle Gesellschaften im 19. und 20 Jabrhundert. Campus Frankfurt; New York, 2004. p.27-63.

LANGLOIS, C. Catholiques et laiques. In: NORA, P. (Ed.) Les lieux de mémoire. Paris: Gallimard, 1997. v.2, p.2327-58.

LAUBE, S. Konfessionelle Brüche in der nationalen Heldengalerie-Protestantische, Katholische und jüdische Erinnerungsgemeinschaften im deutschen Kaiserreich (18711918). In: HAUPT, H.-G.; LANGEWIESCHE, D (Ed.) Nation und Religion in Deutschland. p.293-332. (Consta apenas a obra HAUPT, H.-G.; LANGEWIESCHE, D. Nation und Religion in der deutschen Geschichte. Frankfurt; New York, 2001.)

LEHMANN, H.; KRUMEICH, G. (Ed.) Gott mit uns. Nation, Religion und Gewalt im 19. und frühen 20. Jahrhundert. Göttingen: Vandenhoeck \& Ruprecht, 2000.

MARTIN, J. C. Violence et révolution. Essai sur la naissance d'un mythe national. Paris: Seuil, 1996.

MAYEUR, J. M. La séparation de l'Église et de l'État. Paris: Archives, 1966.

McMANNERS, J. Church and State in France 1870-1914.S.P.CV.K. for the Church Historical Society London, 1972.

MOLLENHAUER, D. Symbolkämpfe um die Nation. Katholiken und Laizisten in Frankreich (1871-1914). In: HAUPT, H.-G.; LANGEWIESCHE, D. Nation und Religion in Europa. Mehrkonfessionelle Gesellschaften im 19. und 10 Jahrhundert. Campus Frankfurt; New York, 2004. p.202-30.

MOSSE, G. L. Die Nationalisierung der Massen. Politische Symbolik und Massenbewegungen in Deutschland von dem Napoleonischen Krieg bis zum Dritten Reich. Frankfurt: Campus, 1976.

MÜLLER, S. O. Die Nation als Waffe und Vorstellung. Nationalismus in Deutschland und Großbritannien im Ersten Weltkrieg. Göttingen: Vandenhoeck \& Ruprecht, 2002.

NORD, P. Political Culture. In: __. The Republican Movement. Struggles for Democracy in Nineteenth-Century France. Cambridge Mass.: Harvard University Press, 1995. p.216ss.

O'BRIEN, C. C. God Land. Reflections on Religion and Nationality. Cambridge Mass.: Harvard University Press, 1988.

OZOUF, M. La fête révolutionnaire: 1789-1799. Paris: Gallimard, 1976.

PAPENHEIM, M. Roma o morte: culture wars in Italy. In: CLARK, C.; KAISER, W. (Ed.) Culture Wars. Secular-Catholic Conflict in Nineteenth Century Europe. Cambridge: Cambridge University Press, 2003. p.202-36. 
REMOND, R. Religion et société en Europe. Essai sur la sécularisation des sociétés européennes aux XIXe et XXe siècles (1789-1998). Paris: Seuil, 1998.

ROUSSEAU, J.-J. Considérations sur le gouvernement de Pologne.in : The plan for perpetual peace.On the government of Poland and other writings on history and politics ed.by C.Kelly, Hanover 2005, University Press of New England.

SCHLESINGER, P. On National Identity. Some Conceptions and Misconceptions Critizised. Social Science Information, v.16, p.260, 1987.

SCHULZE-WESSEL, M. Die Konfessionalisierung der tschechischen Nation. In: HAUPT, H.-G.; LANGEWIESCHE, D. Nation und Religion in Europa. Mehrkonfessionelle Gesellschaften im 19. und 20. Jahrhundert. Frankfurt; New York, 2004. p.13550 .

SCHWEIGER, G. (Ed.) Reformationsjubiläen. Zeitschrift für Kirchengeschichte, v.93, 1982.

STEINMETZ, W. In: HAUPT, H.-G.; LANGEWIESCHE, D (Ed.) Nation und Religion in Deutschland. p.217. (Consta apenas a obra HAUPT, H.-G.; LANGEWIESCHE, D. Nation und Religion in der deutschen Geschichte. Frankfurt; New York, 2001.)

TOBIA, B. Una patria per gli italiani. Spazi, itinerari, monumenti nell'Italia unita, 1870-1900. Roma: Laterza, 1991.

VEROCCI, G. Il XX settembre. In: ISNENGHI, M. (Ed.) Luoghi della memoria. Personaggi e date dell'Italia unita. Roma: Laterza, 1997. p.89ss.

WALKENHORST, P. Nationalismus als "politische Religion”? Zur religiösen Dimension nationalistischer Ideologie im Kaiserreich. In: BLASCHKE, O.; KUHLEMANM, F.-M. (Ed.) Religion im Kaiserreich. Verlag für Regionalgeschichte Gütersloh, 1996. p.503-29.

WEBER, E. Peasants into Frenchmen: the modernization of rural France 1870-1914. Stanford: Stanford University Press, 1976.

France fin de siècle. Cambridge Mass.: Harvard University Press, 1986.

WEHLER, H.-U. Nationalismus. München: Beck, 2003.

WEICHLEIN, S. Der Apostel der Deutschen. In: BLASCHKE, O. (Ed.) Konfessionen im Konflikt. Deutschland zwischen 1800 und 1970: ein zweites konfessionelles Zeitalter. Göttingen: Vandenhoeck \& Ruprecht, 2002. p.155-79.

seldorf, 2006.

Nation und Region. Integrationsprozesse im Bismarckreich. Droste Düs-

WINOCK, M. Jeanne d'Arc. In: NORA, P. (Ed.) Les lieux de mémoire. Paris:: Gallimard, 1997. v.III, p.4427-73.

RESUMO - Este ensaio procura analisar a relação ente nação e religião entre a segunda metade do século XIX e a primeira década do século XX, durante o processo Nation building que se verifica em várias nações européias. Propõe-se aqui uma análise comparada entre os casos de França, Itália, a parte checa do Império Austro-Húngaro e Alemanha. Dando conta das pesquisas mais recentes sobre a afirmação do nacionalismo 
nesse período, rebate-se a afirmação simplista de que o sucesso do nacionalismo dependeu do desmoronamento da religião do final do século XVIII.

PALAVRAS-CHAVE: Religião, Nacionalismo, História comparada, Nation building.

ABSTRACT - This Essay aims to analyze the relation between nation and religion from the second half of the $19^{\text {th }}$ century to the first decade of the $20^{\text {th }}$ century, during the process of Nation building that could be observed in several European nations. We propose a comparative analysis of the following cases: France, Italy, the Czech part of the AustroHungarian Empire, and Germany. Considering the recent researches on the affirmation of nationalism in that period, we respond to the simplistic statement that the success of nationalism depended on the ruin of religion after the end of the $18^{\text {th }}$ century.

KErWORDS: Religion, Nationalism, Comparative history, Nation Building.

Heinz-Gerhard Haupt é professor de História Social Contemporânea do Instituto Europeu de Fiesole (Toscana). É autor e editor de Nation und Religion in Europa. Mehrkonfessionelle Gesellschaften im 19. und 20. Jahrhundert (Frankfurt; New York, 2004); Aufbruch in die Zukunft (Göttingen, 2004); Terrorismus in der Bundesrepublik: Medien, Staat und Subkulturen in den 1970er Jahren (Frankfurt am Main 2006). @ - HeinzGerhard.Haupt@EUI.eu

Tradução de Paulo Butti de Lima. O original em italiano - "Religion et nation en Europe au $19^{\mathrm{e}}$ siècle: quelques remarques comparatives" - encontra-se à disposição do leitor no IEA-USP para eventual consulta.

Recebido em 22.1.2007 e aceito em 19.2.2007. 